\title{
Analisis Pengaruh Corporate Social Responsibility terhadap Nilai Perusahaan dengan Profitabilitas, Kepemilikan Manajemen, dan Ukuran Perusahaan sebagai Variabel Moderasi (Studi Empiris pada Perusahaan Pertambangan yang Terdaftar di Bursa Efek Indonesia Tahun 2012 - 2016)
}

\author{
FRANDY KARUNDENG ${ }^{1}$, GRACE B. NANGOI ${ }^{2}$, HERMAN KARAMOY ${ }^{3}$
}

\author{
1,2,3ProgramStudi MagisterAkuntansi, Fakultas Ekonomi dan Bisnis Universitas Sam Ratulangi \\ email:frandykarundeng@gmail.com ${ }^{1}$, gracebn@yahoo.com²
}

\begin{abstract}
The corporate's responsibility currently has evolved into a triple bottom line principal which directs the corporates for are not only focused on its profit achievement (profit), but also to secure the environmental sustainability (planet) and contribute in the community development (people). In accordance to the Indonesia's Act, any company, which activities are in exploiting the natural resources (SDA), is obliged to implement the social and environmental responsibility. It is usually called as the Corporate Social Responsibility (CSR). The mining corporates are, thus, must implement the CSR. The aims of this study are to verify (1) the influence of CSR to increase the firm value, and (2) the influence of profitability, management ownership, and firm size (as the factors to moderate the relationship amongst CSR) to the firm value. CSR disclosure is measured by GRI (G4) index. The firm value variable is then calculated by using Tobin's $Q$ ratio. Profitability variable, management ownership variable, and company size variable are each measured by ROE, percentage of management ownership, and natural logarithm of total asset. The result of this study concludes that CSR does not affect firm value. Management ownership and firm size do not influence either firm value. On the other hand, the profitability has a positive effect on the firm value. Furthermore, profitability as a moderating variable can strengthen the relationship between CSR and firm value. However, this study draws conclusion that management ownership and firm size do not strengthen the relationship among CSR and firm value.
\end{abstract}

Keywords: CSR, Profitability, Management Ownership, Firm Size, and Firm Value.

\begin{abstract}
Abstrak. Saat ini tanggung jawab perusahaan sudah berkembang menjadi prinsip triple bottom line, yang mengarahkan perusahaan untuk tidak hanya fokus pada pencapaian profit saja, tetapi juga mampu menjaga kelestarian lingkungan (planet) dan memberikan kontribusi dalam pengembangan masyarakat (people). Sesuai dengan amanat UU, setiap perseroan terbatas yang kegiatannya memanfaatkan SDA wajib untuk melaksanakan Tanggung Jawab Sosial dan Lingkungan (TJSL).Oleh karena itu, perusahaan pertambangan merupakan perusahaan yang tergolong wajib melaksanakan TJSL atau CSR. Melalui penelitian ini, ingin diketahui pengaruh $C S R$ dalam meningkatkan nilai perusahaan pertambangan yang aktivitasnya memanfaatkan SDA, serta pengaruh profitabilitas, kepemilikan manajemen, dan ukuran perusahaan sebagai faktor yang memoderasi hubungan antara CSR dan nilai perusahaan. Pengungkapan CSR diukur dengan menggunakan indikator yang dikeluarkan oleh lembaga internasional General Reporting Initiative (GRI) yaitu indeks G4. Kemudian variabel nilai perusahaan dihitung dengan menggunakan rasio Tobin's Q, serta variabel profitabilitas, kepemilikan manajemen, dan ukuran perusahaan masing-masing diukur dengan $R O E$, persentase kepemilikan manajemen, dan logaritma natural dari total aset perusahaan. Hasil penelitian ini menyimpulkan bahwa CSR tidak berpengaruh terhadap nilai perusahaan. Hasil yang sama juga terdapat pada pengaruh kepemilikan manajemen dan ukuran perusahaan secara parsial terhadap nilai perusahaan. Sedangkan profitabilitas berpengaruh positif terhadap nilai perusahaan.Kemudian, profitabilitas sebagai variabel moderasi mampu memperkuat hubungan antara CSR dan nilai perusahaan.Akan tetapi, dalam penelitian ini menyimpulkan bahwa kepemilikan manajemen dan ukuran perusahaan tidak memperkuat hubungan antara CSR dan nilai perusahaan.
\end{abstract}

Kata kunci : CSR, Profitabilitas, Kepemilikan Manajemen, Ukuran Perusahaan, dan Nilai Perusahaan.

\section{Pendahuluan}

Selaras dengan perkembangan ekonomi yang semakin pesat di era globalisasi ini, tantangan bagi perusahaan untuk mencapai tujuan perusahaan termasuk menerapkan prinsip going concern atau keberlanjutan usaha pun semakin bertambah. Setiap perusahaan melalui kegiatan operasinya akan selalu berusaha untuk mencapai tujuannya, yaitu meningkatkan nilai perusahaan. Menurut McWilliams and Siegel (2000), nilai perusahaan dapat meningkat secara berkelanjutan tidak hanya dijamin oleh kinerja keuangan yang baik saja, karena pengambilan keputusan oleh investor yang hanya berdasarkan pada kinerja keuangan tidak lagi relevan dengan dunia bisnis di era globalisasi saat ini. Keberlanjutan perusahaan (corporate sustainability) hanya akan terjamin apabila perusahaan memperhatikan dimensi sosial dan lingkungan hidup. Crowther dan Aras (2008 : 55) mengatakan bahwa etika bisnis merupakan landasan pemikiran suatu perusahaan melakukan tanggung jawab sosialnya atau yang lebih dikenal dengan Corporate Social Responsibility (CSR).

Perhatian Pemerintah Indonesia akan pentinganya CSR diwujudkan dengan membuat Undang-undang Perseroan Terbatas Nomor 40 Tahun 2007, Pasal 74 meyatakan bahwa "Perseroan yang menjalankan kegiatan usahanya di bidang atau berkaitan dengan Sumber Daya Alam (SDA) wajib melaksanakan Tanggung Jawab Sosial dan Lingkungan (TJSL)". Perusahaan pertambangan merupakan contoh industri yang wajib melaksanakan 
CSR dan mengungkapkannya dalam annual report karena aktivitas usahanya memanfaatkan SDA yang berdampak secara langsung pada lingkungan.

Agustine (2014) dalam penelitiannya mengatakan bahwa CSR harus didukung oleh variabel moderasi untuk lebih memperkuat pengaruhnya terhadap nilai perusahaan. Variabel moderasi merupakan variabel yang memperkuat tetapi juga bisa memperlemah hubungan antara variabel independen dengan variabel dipenden (Sujarweni, 2016 : 277). Profitabilitas merupakan variabel moderasi yang memperkuat hubungan CSR dan nilai perusahaan karena profitabilitas yang tinggi membuat manajemen menjadi bebas dan fleksibel dalam melaksanakan dan mengungkapkan CSR (Anggraini, 2006).Kepemilikan manajerial merupakan variabel pemoderasi yang memperkuat hubungan antara CSR dan nilai perusahaan, karena semakin besar kepemilikan manajer di dalam perusahaan, maka manajer akan semakin banyak melaksanakan dan mengungkapkan informasi sosial dari kegiatan-kegiatan yang telah dilakukan di dalam program Tanggung Jawab Sosial Perusahaan (TJSP) (Putri dan Raharja, 2013). Menurut Adam and Hardwick (1998), semakin besar ukuran perusahaan maka kewajiban perusahaan dalam melakukan CSR juga akan semakin besar. Perusahaan besar merupakan emiten yang paling banyak disoroti oleh publik sehingga pengungkapannya yang lebih besar merupakan pengurangan biaya politis sebagai wujud TJSP (Sembiring, 2006).

Berdasarkan latar belakang di atas maka penulis merumuskan masalah penelitian sebagai berikut:

1) Apakah CSR berpengaruh terhadap nilai perusahaan pada perusahaan pertambangan yang terdaftar di BEI Tahun 2012 - 2016?

2) Apakah profitabilitas berpengaruh terhadap nilai perusahaan pada perusahaan pertambangan yang terdaftar di BEI Tahun 2012 - 2016?

3) Apakah kepemilikan manajemen berpengaruh terhadap nilai perusahaan pada perusahaan pertambangan yang terdaftar di BEI Tahun $2012-2016$ ?

4) Apakah ukuran perusahaan berpengaruh terhadap nilai perusahaan pada perusahaan pertambangan yang terdaftar di BEI Tahun 2012 - 2016?

5) Apakah profitabilitas berpengaruh terhadap hubungan antara CSR dan nilai perusahaan pada perusahaan pertambangan yang terdaftar di BEI Tahun 2012 - 2016?

6) Apakah kepemilikan manajemen berpengaruh terhadap hubungan antara CSR dan nilai perusahaan pada perusahaan pertambangan yang terdaftar di BEI Tahun $2012-2016$ ?

7) Apakah ukuran perusahaan berpengaruh terhadap hubungan antara CSR dan nilai perusahaan pada perusahaan pertambangan yang terdaftar di BEI Tahun 2012 - 2016?

Tujuan yang hendak dicapai dalam penelitian ini adalah untuk mengui secara empiris semua rumusan masalah yang ada.

Manfaat yang diharapkan dalam penelitian iniadalah sebagai tambahan ilmu pengetahuan dalam bidang akuntansi dan manajemen keuangan. Bagi perusahaan, diharapkan dapat memberikan masukan dan tambahan informasi dalam proses pengambilan keputusan terutama dalam aspek nilai perusahaan yang berkaitan dengan $C S R$, profitabilitas, kepemilikan manajemen, dan ukuran perusahaan.Bagi pihak investor, diharapkan dapat membantu dalam proses pengambilan keputusan investasi, yaitu dari aspek pengungkapan kegiatan CSR perusahaan. Bagi peneliti lainnya, hasil penelitian ini dapat digunakan sebagai referensi atau penelitian terdahulu untuk membuat suatu penelitan baru atau pengembangan selanjutnya.Bagi penulis, proses penelitian ini memberi kesempatan untuk mengaplikasikan ilmu pengetahuan yang telah dipelajari selama kuliah kedalam karya nyata.

Gambar 1. Rerangka Konseptual Penelitian

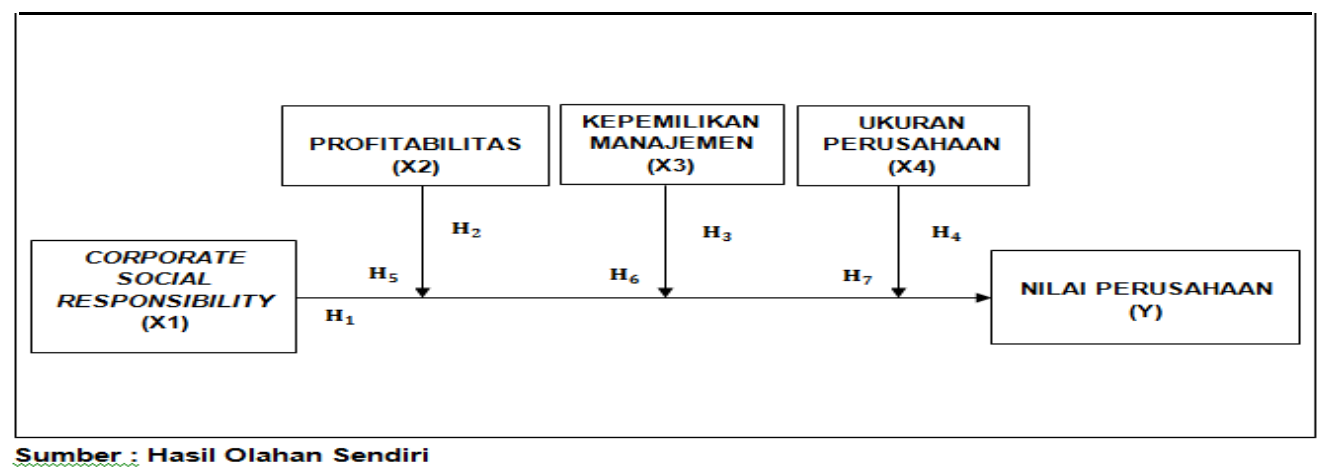

Berdasarkan landasan teori dan hasil-hasil penelitian terdahulu, maka hipotesa dalam penelitian ini dirumuskan menjadi tujuh hipotesa.

\section{Pengaruh CSR terhadap Nilai Perusahaan Publik Sektor Pertambangan.}

Ghoul et al (2011) mengatakan bahwa secara teoritis, semakin banyaknya aktivitas CSR yang diungkapkan oleh perusahaan, maka nilai perusahaan akan semakin meningkat karena pasar akan memberikan apresiasi positif kepada perusahaan yang melakukan CSR yang ditunjukkan dengan peningkatan harga saham perusahaan. Investor mengapresiasi praktik CSR dan melihat aktivitas 
CSR sebagai pedoman untuk menilai potensi keberlanjutan suatu perusahaan.Oleh sebab itu, dalam mengambil keputusan investasi, banyak investor yang cukup memperhatikan CSR yang diungkapkan oleh perusahaan.Perumusan hipotesa mengenai pengaruh CSR terhadap nilai perusahaan sebagai berikut.

$\mathrm{H}_{1}$ : $C S R$ berpengaruh positif terhadap nilai perusahaan publik sektor pertambangan.

2. Pengaruh Profitabilitas terhadap Nilai Perusahaan Publik Sektor Pertambangan.

Profitabilitas adalah salah satu faktor yang berpengaruh terhadap nilai perusahaan, karena menjadi salah satu indikator penting bagi investor dalam menilai prospek perusahaan di masa depan dengan melihat sejauh mana pertumbuhan profitabilitas perusahaan (Tandelilin, 2001 : 240). Harga saham yang meningkat mencerminkan nilai perusahaan yang baik bagi investor. Harga saham akan ikut meningkat, apabila kemampuan perusahaan dalam menghasilkan laba juga meningkat atau profitabilitas meningkat Husnan (2001 : 317). Perumusan hipotesa mengenai pengaruh profitabilitas terhadap nilai perusahaan sebagai berikut.

$\mathrm{H}_{2}$ : Profitabilitas berpengaruh positif terhadap nilai perusahaan publik sektor pertambangan.

\section{Pengaruh Kepemilikan Manajemen terhadap Nilai Perusahaan Publik Sektor} Pertambangan.

Menurut Haruman (2008) perbedaan kepentingan antara manajemen dan pemegang saham mengakibatkan manajemen berprilaku curang dan tidak etis sehingga merugikan pemegang saham.(Ramadhani, 2012) mengatakan bahwa diperlukan suatu mekanisme pengendalian yang dapat mensejajarkan kepentingan antara manajemen dengan saham. Manajer yang sekaligus pemegang saham akan meningkatkan nilai perusahaan karena dengan meningkatkan nilai perusahaan, maka nilai kekayaannya sebagai pemegang saham juga akan meningkat.Perumusan hipotesa mengenai pengaruh kepemilikan manajemen terhadap nilai perusahaan sebagai berikut.

$\mathbf{H}_{3}$ : Kepemilikan manajemen berpengaruh positif terhadap nilai perusahaan publik sektor pertambangan.

4. Pengaruh Ukuran Perusahaan terhadap Nilai Perusahaan Publik Sektor Pertambangan.

Ukuran perusahaan dianggap mampu untuk memengaruhi nilai dari suatu perusahaan (Martini, 2014). Semakin besar ukuran atau skala perusahaan maka akan semakin mudah perusahaan dalam memeroleh sumber pendanaan baik yang bersifat internal maupun eksternal. Semakin besar ukuran perusahaan, maka berdampak pada semakin banyaknya investor yang menaruh perhatian pada perusahaan tersebut (Mahatma, 2013).Perumusan hipotesa mengenai pengaruh ukuran perusahaan terhadap nilai perusahaan sebagai berikut.

$\mathbf{H}_{4}$ : Ukuran perusahaan berpengaruh positif terhadap nilai perusahaan publik sektor pertambangan.

5. Pengaruh Profitabilitas sebagai Pemoderasi pada Hubungan antara CSR dan Nilai Perusahaan Publik Sektor Pertambangan.

Kamil \& Herusetya (2012) berpendapat bahwa tingkat profitabilitas yang semakin besar menunjukkan perusahaan mampu mendapatkan laba yang semakin besar, sehingga perusahaan mampu untuk meningkatkan aktivitas tanggung jawab sosial, serta mengungkapkan tanggung jawab sosialnya dalam laporan tahunan dengan lebih luas.Semakin tinggi profitabilitas perusahaan, maka semakin besar pengungkapan informasi sosial yang dilakukan oleh perusahaan (Bowman dan Haire, 1988). Sehingga dapat disimpulkan bahwa, CSRakan meningkatkan nilai perusahaan pada saat profitabilitas perusahaan meningkat (Hackston dan Milne, 1996).Perumusan hipotesa mengenai pengaruh interaksi $C S R$ dan profitabilitas terhadap nilai perusahaan sebagai berikut.

$\mathrm{H}_{5}$ : Profitabilitas memperkuat hubungan antara $C S R$ dan nilai perusahaan publik sektor pertambangan.

6. Pengaruh Kepemilikan Manajemen sebagai Pemoderasi pada Hubungan antara $C S R$ dan Nilai Perusahaan Publik Sektor Pertambangan.

Siallagan dan Machfoedz (2006) menyebutkan bahwa semakin besar kepemilikan manajemen dalam perusahaan maka manajemen akan cendrung meningkatkan kinerjanya untuk kepentingan pemegang saham dan untuk kepentingannya sendiri. Gray et al, (1988) menyebutkan bahwa manajer akan mengungkapkan informasi sosial dalam rangka untuk meningkatkan image perusahaan, meskipun ia harus mengorbankan sumber daya yang ada untuk aktivitas tersebut. Fuerst dan Kang (2004) menemukan hubungan yang positif antara kepemilikan internal dengan nilai pasar setelah mengendalikan kinerja perusahaan. Hubungan positif tersebut secara teori dijelaskan bahwa kepemilikan manajemen yang tinggi dapat mengurangi konflik agensi karena 
tindakan manajer yang semakin produktif dalam memaksimalkan nilai perusahaan, sehingga manajer akan mengungkapkan informasi sosial dalam rangka meningkatkan image perusahaan. Perumusan hipotesa mengenai pengaruh interaksi CSR dan kepemilikan manajemen terhadap nilai perusahaan sebagai berikut.

$\mathrm{H}_{6}$ : Kepemilikan manajemen memperkuat hubungan antara $C S R$ dan nilai perusahaan publik sektor pertambangan.

7. Pengaruh Ukuran Perusahaan sebagai Pemoderasi pada Hubungan antara $C S R$ dan Nilai Perusahaan Publik Sektor Pertambangan.

Menurut Cowen, Ferreri, dan Parker (1987), perusahaan yang besar diharapkan bisa mengungkapkan informasi CSR yang menjelaskan tentang perhatian perusahaan kepada masyarakat dan lingkungan, yang bisa mempertahankan legitimasi perusahaan. Dengan kata lain semakin besar aset suatu perusahaan maka akan semakin besar tanggung jawab sosialnya, dan hal ini akan dilaporkan dalam laporan tahunan, sehingga pengungkapannya juga semakin luas (Lerner dan Fryxell 1988). Perumusan hipotesa mengenai pengaruh Interaksi CSR dan ukuran perusahaan terhadap nilai perusahaan sebagai berikut.

$\mathrm{H}_{7}$ : Ukuran perusahaan memperkuat hubungan antara $C S R$ dan nilai perusahaan publik sektor pertambangan.

\section{Metode Penelitian}

Jenis penelitian yang dilakukan adalah jenis penelitian kuantitatif. Populasi dari penelitian ini adalah keseluruhan perusahaan publik sektor pertambangan yang terdaftar di Bursa Efek Indonesia (BEI) selama periode 2012 - 2016. Kriteria sampel yang digunakan dalam penelitian ini adalah Perusahaan pertambangan yang terdaftar di Bursa Efek Indonesia selama tahun 2012 - 2016, mempublikasikan annual report secara berturut-turut selama tahun 2012 - 2016 di situs resmi Bursa Efek Indonesia atau di situs resmi perusahaan, data harga saham, profitabilitas, presentase kepemilikan manajemen, total aset perusahaan, dan data pengungkapan CSR tersedia secara lengkap selama periode pengamatan, dan perusahaan pertambangan yang memperoleh laba selama periode pengamatan yaitu tahun 2012 - 2016. Total sampel dalam penelitian ini adalah Sembilan perusahaan. Teknik analisis data menggunakan uji asumsi normalitas dan uji asumsi klasik multikolinearits dan uji heterokedastisitas, serta uji hipotesis yaitu uji statistik t. Model analisis regresi linier berganda sebagai berikut.

$$
Y=\alpha+\beta_{1} X_{1}+\beta_{2} X_{2}+\beta_{3} X_{3}+\beta_{4} X_{4}+\beta_{5} X_{1} X_{2}+\beta_{6} X_{1} X_{3}+\beta_{7} X_{1} X_{4}+e
$$

Variabel nilai perusahaan dalam perhitungan menurut rasio Tobin's Q disimbolkan dengan Q. Menurut “Herawaty (2008) Tobin's Q dapat dirumuskan sebagai berikut :

$$
Q=\frac{E M V+D}{E B V+D}
$$

Keterangan:

$$
\begin{array}{ll}
\text { Q } & \text { : Nilai perusahaan } \\
\text { EMV } & \text { :Nilai pasar ekuitas } \\
\text { EBV } & \text { :Nilai buku dari ekuitas } \\
\text { D } & \text { :Nilai buku dari total utang }
\end{array}
$$

Pengukuran dilakukan berdasarkan indeks pengungkapan masing-masing perusahaan yang dihitung melalui jumlah item yang sesungguhnya diungkapkan perusahaan dengan jumlah semua item yang mungkin diungkapkan. Menurut Rosiana et al(2013) CSR disclosure index dinotasikan dalam rumus sebagai berikut :

$$
\begin{aligned}
& \operatorname{CSRDI}_{j}=\frac{\mathrm{n}}{\mathrm{k}} \\
& \text { Keterangan: } \\
& \operatorname{CSRDI}_{j}: \text { CSR disclosure index perusahaan } \mathrm{j} \\
& \mathrm{n} \quad: \text { Jumlah item pengungkapan } C S R \text { yang terpenuhi } \\
& \mathrm{k} \quad: \text { Jumlah semua item pengungkapan } C S R(91 \text { item })
\end{aligned}
$$

Pengukuran CSRDI dilakukan dengan menggunakan :

Score 0 : Jika perusahaan tidak mengungkapkan item checklist.

Score 1 : Jika perusahaan mengungkapkan item checklist.

Pengukuran profitabilitas perusahaan diproksikan menggunakan ROE. ROE dapat dihitung dengan menggunakan rumus sebagai berikut (Brigham \& Houston, 2012 : 110). 
$R O E=\frac{E A T}{\text { Total Equity }}$

Keterangan :

$\mathrm{ROE}$ :Return on Equity

EAT :Earning after Tax

Kepemilikan manajemen d diformulasikan sebagai berikut (Ramadhani, 2012):

$\mathrm{KM}=\frac{\text { Saham Direksi dan Saham Komisaris }}{\text { Total Saham yang Beredar }} \times 100 \%$

Keterangan:

KM : Kepemilikan manajemen Rubin, 2005)

Ukuran perusahaan diukur dengan menggunakan Log Natural Total Aset (Ln Total Aset) (Barnea and

Firm Size $=$ Natural Log of Total Assets

\section{Hasil Dan Pembahasan}

Uji Statistik Deskriptif

Tabel 1. Statistik Deskriptif Variabel Penelitian

\begin{tabular}{|l|r|r|r|r|r|}
\hline \multicolumn{7}{|c|}{ Descriptive Statistics } \\
\hline NILAI PERUSAHAAN & \multicolumn{1}{|c|}{ M } & \multicolumn{1}{c|}{ Minimum } & \multicolumn{1}{c|}{ Maximum } & \multicolumn{1}{c|}{ Mean } & \multicolumn{1}{c|}{ Std. Deviation } \\
CSR & 45 & .5284541 & 4.3012930 & 1.808042362 & 1.0924991130 \\
PROFITABILITAS & 45 & .3736264 & .9780220 & .614896222 & .1929553262 \\
KEPEMILIKAN & .0061094 & .7114087 & .146501309 & .1295593758 \\
MANAJEMEN & 45 & $1 \mathrm{E}-7$ & .6665049 & .088948036 & .1929349274 \\
UKURAN PERUSAHAAN & 45 & 26.2894650 & 32.1091535 & 29.119986551 & 1.5352941567 \\
Valid N (listwise) & 45 & & & & \\
\hline
\end{tabular}

Sumber : Data Sekunder Hasil Olahan Sendiri, 2017.

Uji Normalitas. Berdasarkan hasil uji K-S diketahui nilai signifikansi lebih besar dari 0.05, yaitu sebesar 0.205.Dengan demikian dapat disimpulkan bahwa data dalam penelitian ini berdistribusi normal atau model regresinya layak digunakan karena memenuhi asumsi normlitas.

Tabel 2 Hasil Uji Kolmogorov-Smirnov

\begin{tabular}{|ll|r|}
\hline \multicolumn{2}{|c|}{ One-Sample Kolmogorov-Smirnov Test } \\
\hline $\mathrm{N}$ & \multicolumn{1}{|c|}{$\begin{array}{c}\text { Unstandardized } \\
\text { Residual }\end{array}$} \\
\hline & & 45 \\
Normal Parameters ${ }^{\mathrm{a}, \mathrm{b}}$ & Mean & $0 \mathrm{E}-7$ \\
& Std. & 1.06534093 \\
& Deviation & .159 \\
Most Extreme Differences & Absolute & .159 \\
& Positive & -.102 \\
Kolmogorov-Smirnov Z & Negative & .2067 \\
\hline Asymp. Sig. (2-tailed) & & .205 \\
\hline a. Test distribution is Normal. & & \\
b. Calculated from data. & & \\
\hline
\end{tabular}

Sumber: Hasil Olahan Sendiri, 2017.

Uji Multikolinearitas. Nilai $V I F$ dari semua variabel bebas juga berada di antara 1 - 10, yaitu 2.258 untuk nilai variabel $C S R$, nilai 1.142 untuk variabel profitabilitas, nilai 1.036 untuk variabel kepemilikan manajemen, dan nilai 2.093 untuk variabel ukuran perusahaan. Oleh karena itu, dapat disimpulkan bahwa tidak terdapat masalah kemeripan antar variabel independen atau tidak terjadi masalah multikolinieritas dalam model regresi yang diteliti. 
Tabel 3 Hasil Uji Multikolinieritas

\begin{tabular}{|c|c|c|c|c|c|c|c|}
\hline \multicolumn{8}{|c|}{ Coefficients ${ }^{\mathrm{a}}$} \\
\hline \multirow[t]{2}{*}{ Model } & \multicolumn{2}{|c|}{$\begin{array}{c}\text { Unstandardized } \\
\text { Coefficients }\end{array}$} & $\begin{array}{l}\text { Standardized } \\
\text { Coefficients }\end{array}$ & \multirow[t]{2}{*}{$\mathrm{t}$} & \multirow[t]{2}{*}{ Sig. } & \multicolumn{2}{|c|}{ Collinearity Statistics } \\
\hline & $\mathrm{B}$ & Std. Error & Beta & & & Tolerance & VIF \\
\hline (Constant) & 4.143 & 4.119 & & 1.006 & .320 & & \\
\hline CSR & .118 & 1.312 & .021 & .090 & .929 & .443 & 2.258 \\
\hline PROFITABILITAS & .712 & 1.389 & .084 & .513 & .611 & .876 & 1.142 \\
\hline $\begin{array}{l}\text { KEPEMILIKAN } \\
\text { MANAJEMEN }\end{array}$ & 1.046 & .889 & .185 & 1.177 & .246 & .965 & 1.036 \\
\hline $\begin{array}{l}\text { UKURAN } \\
\text { PERUSAHAAN }\end{array}$ & -.089 & .159 & -.126 & -.564 & .576 & .478 & 2.093 \\
\hline
\end{tabular}

Sumber : Hasil Olahan Sendiri, 2017.

Uji Heterokedastisitas. Dasar pengambilan keputusan adalah jika nilai signifikansi lebih besar dari 0.05, maka tidak terjadi heterokedastisitas. Semua variabel memiliki nilai signifikansi lebih besar dari 0.05.

Tabel 4 Hasil Uji Glejser

\begin{tabular}{|c|c|c|c|c|c|c|}
\hline \multicolumn{7}{|c|}{ Coefficients $^{\mathrm{a}}$} \\
\hline \multirow{2}{*}{\multicolumn{2}{|c|}{ Model }} & \multicolumn{2}{|c|}{$\begin{array}{c}\text { Unstandardized } \\
\text { Coefficients }\end{array}$} & $\begin{array}{l}\text { Standardized } \\
\text { Coefficients }\end{array}$ & \multirow[t]{2}{*}{$\mathrm{t}$} & \multirow[t]{2}{*}{ Sig. } \\
\hline & & $\mathrm{B}$ & Std. Error & Beta & & \\
\hline & (Constant) & .967 & 2.185 & & .443 & .660 \\
\hline & CSR & -.958 & .696 & -.312 & -1.376 & .176 \\
\hline & PROFITABILITAS & .804 & .737 & .176 & 1.092 & .282 \\
\hline & $\begin{array}{l}\text { KEPEMILIKAN } \\
\text { MANAJEMEN }\end{array}$ & -.138 & .471 & -.045 & -.293 & .771 \\
\hline & $\begin{array}{l}\text { UKURAN } \\
\text { PERUSAHAAN }\end{array}$ & .013 & .084 & .035 & 160 & .874 \\
\hline
\end{tabular}

Sumber : Hasil Olahan Sendiri, 2017

Analisis Regresi. Hasil analisis regresi linier berganda sebagai berikut.

$Y=-17.079+30.484 X_{1}-10.399 X_{2}+5.116 X_{3}+0.717 X_{4}+21.567 X_{1} X_{2}-6.852 X_{1} X_{3}-1.182 X_{1} X_{4}+e$

Ringkasan hasil analisis regresi linier berganda dapat diketahui pada Tabel 5.

Tabel 5. Ringkasan Hasil Analisis Regresi Linier Berganda

\begin{tabular}{|c|c|c|c|}
\hline Nama Variabel & Beta & t-hitung & Sig. \\
\hline Konstanta & -17.079 & & \\
\hline CSR & 30.848 & 0.989 & 0.329 \\
\hline Profitabilitas & -10.399 & -2.530 & 0.016 \\
\hline Kepemilikan Manajemen & 5.116 & 0.745 & 0.461 \\
\hline Ukuran Perusahaan & 0.717 & 1.360 & 0.182 \\
\hline Moderasi CSR dan Profitabilitas & 21.567 & 2.801 & 0.008 \\
\hline Moderasi CSR dan Kepemilikan Manajemen & -6.852 & -0.555 & 0.582 \\
\hline Moderasi CSR dan Ukuran Perusahaan & -1.182 & -1.161 & 0.253 \\
\hline
\end{tabular}

Sumber : Hasil Olahan Sendiri, 2017.

Koefisien Determinasi $\left(\mathbf{R}^{2}\right)$. Nilai $\mathrm{R}^{2}$ sebesar 0.292 menunjukkan bahwa semua variabel independen yaitu CSR, profitabilitas, kepemilikan manajemen, dan ukuran perusahaan dapat mempengaruhi nilai perusahaan sebesar 29.20\%. Sedangkan sisanya 70.80\% dipengaruhi oleh variabel lain di luar model.

\section{Uji Hipotesis 1 : $\quad$ CSR berpengaruh positif terhadap nilai perusahaan publik sektor pertambangan.}

Hasil penelitian ini menunjukkan bahwa CSR tidak berpengaruh terhadap nilai perusahaan publik sektor pertambangan yang terdaftar di Bursa Efek Indonesia periode tahun 2012 - 2016.Uji hipotesis menunjukkan angka signifikansi sebesar 0.329 (>0.05), sehingga $\mathrm{H} 1$ didukung secara statistik.

Hasil penelitian ini menunjukkan bahwa persuahaan belum melakukan pengkomunikasian tanggung jawab sosial secara komprehensif kepada stakeholder dan shareholder. Hasil penelitian ini sama dengan hasil 
penelitian yang dilakukan oleh Nurlela dan Islahudin (2008), yaitu CSR tidak berpengaruh signifikan terhadap nilai perusahaan.

CSR tidak berpengaruh terhadap nilai perusahaan dalam penelitan ini disebabkan oleh luas pengungkapan CSR pada perusahaan sektor pertambangan yang terdaftar di BEI selama tahun 2012 - 2016 masih sangat rendah.Hal ini juga disebabkan oleh belum adanya regulasi dari pemerintah mengenai indikatorindikator CSR yang harus diungkapkan dalam annual report.Peraturan pemerintah yang berlaku saat ini hanyalah tentang penyampaian laporan tahunan emiten atau perusahaan publik (Peraturan Bapepam Nomor X. K.6). Dalam peraturan ini, tidak memuat secara rinci tentang indikator-indikator apa yang seharusnya diungkap oleh perusahaan publik di laporan tahunan perusahaan.

Secara umum, yang menjadi patokan dalam pengungkapan CSR adalah standar Global Reporting Initiative (GRI) yang berlaku secara internasional.Pada standar GRI 4 yang merupakan versi terbaru mengenai indikator pengungkpan $C S R$ pada laporan keberlanjutan dan/atau laporan tahunan terdapat 91 indikator yang harus diungkapkan.Masih banyak perusahaan pertambangan yang menjadi sampel dalam penelitian ini belum menggunakan standar GRI dalam mengungkapakan kegiatan CSR perusahaan.Hanya dua perusahaan yang menggunakan standar GRI secara jelas dalam laporan keberlanjutan dan/atau disatukan dalam laporan tahunan perusahaan, yaitu PT Indo Tambangraya Megah Tbk dan PT Tambang Batubara Bukit Asam (Persero) Tbk.

\section{Uji Hipotesis 2: $\quad$ Profitabilitas berpengaruh positif terhadap nilai perusahaan publik sektor pertambangan.}

Hasil penelitian ini menunjukkan bahwa profitabilitas berpengaruh positif terhadap nilai perusahaan publik sektor pertambangan yang terdaftar di Bursa Efek Indonesia periode tahun $2012-2016$.Uji hipotesis menunjukkan angka signifikansi sebesar $0.016(<0.05)$, sehingga $\mathrm{H} 2$ didukung secara statistik.

Hasil penelitian ini sesuai dengan hasil penelitian yang dilakukan oleh Soliha dan Taswan (2002), serta Hemastuti (2014) yang menyimpulkan bahwa profitabilitas mempunyai pengaruh positif terhadap nilai perusahaan. Profitabilitas yang tinggi menunjukkan kemampuan perusahaan yang tinggi untuk menghasilkan laba dari modal sendiri, hal ini tentunya akan menarik investor untuk berinvestasi yang pada akhirnya akan menyebabkan naiknya harga saham yang berarti juga kenaikan dalam nilai perusahaan begitu pun sebaliknya, profitabilitas yang rendah bisa menurunkan nilai perusahaan (Analisa, 2009).

\section{Uji Hipotesis 3 : Kepemilikan manajemen berpengaruh positif terhadap nilai perusahaan publik sektor pertambangan.}

Hasil penelitian ini menyimpulkan bahwa kepemilikan manajemen tidak berpengaruh terhadap nilai perusahaan publik sektor pertambangan yang terdaftar di Bursa Efek Indonesia periode tahun 2012 - 2016.Uji hipotesis menunjukkan angka signifikansi sebesar $0.461(>0.05)$, sehingga H1 tidak didukung secara statistik.

Hasil penelitian ini menunjukkan bahwa kepemilikan manajemen tidak mempengaruhi nilai perusahaan, karena secara statistik deskriptif diketahui bahwa kepemilikan manajerial rata-rata perusahaan yang menjadi sampel penelitian adalah sebesar $8,89 \%$, nilai sebesar ini relatif sangat sedikit untuk dimiliki dewan komisaris dan direksi dalam manajemen mengingat nilai kapitalisasi pasar perusahaan secara keseluruhan adalah tinggi. Hal ini menyebabkan pengaruh kepemilikan manajemen tidak signifikan untuk meningkatkan nilai perusahaan.

\section{Uji Hipotesis 4: Ukuran perusahaan berpengaruh positif terhadap nilai perusahaan publik sektor pertambangan.}

Hasil penelitian ini menunjukkan bahwa ukuran perusahaan tidak berpengaruh terhadap nilai perusahaan publik sektor pertambangan yang terdaftar di Bursa Efek Indonesia periode tahun 2012 - 2016.Uji hipotesis menunjukkan angka signifikansi sebesar 0.182 (>0.05), sehingga secara statistik tidak mendukung H1.

Hasil penelitian ini kemungkinan disebabkan oleh besarnya total aktiva sebagai ukuran perusahaan belum memberikan keyakinan kepada investor tentang kemampuan perusahaan dalam mengelola aset yang ada. Jika perusahaan memiliki total aset yang besar, pihak manajemen akan lebih leluasa dalam mempergunakan aset yang ada di persuahaan tersebut. Kebebasan yang dimiliki manajemen ini sebanding dengan kekhawatiran yang dirasakan oleh pemilik asetnya (Suharli, 2006).

Pada dasarnya ukuran perusahaan dapat dilihat dari total aktivanya, perusahaan dengan total aktiva yang besar dengan komponen dominan pada piutang dan persediaan belum tentu dapat membayar deviden dikarenakan aset yang menumpuk pada piutang dan persediaan. Perusahaan lebih memperhatikan laba dibandingkan dengan membagikannya sebagai dividen, yang dapat mempengaruhi harga saham dan nilai perusahaan (Suwarno, Puspito dan Qomariah, 2016). Dengan begitu, perusahaan yang memiliki total aset yang besar belum tentu memberikan keyakinan kepada investor dalam mengelola perusahaan agar dapat meningkatkan nilai perusahaan.

Hasil penelitian ini juga mengindikasikan bahwa investor membeli saham sebuah perusahaan tidak hanya ditinjau dari seberapa besar aktiva perusahaan namun juga dari sisi lain, seperti kinerja keuangan perusahaan. Kinerja keuangan perusahaan yang baik, yang tercermin pada tingkat profitabilitas perusahaan sering menjadi penilaian utama saat investor akan melakukan investasi pada perusahaan. 


\section{Uji Hipotesis 5 : Profitabilitas memperkuat hubungan antara CSR dan nilai perusahaan publik sektor}

pertambangan.

Hasil penelitian ini menunjukkan bahwa profitabilitas perusahaan memperkuat hubungan antara CSR dan nilai perusahaan publik sektor pertambangan yang terdaftar di Bursa Efek Indonesia periode tahun 2012 2016.Uji hipotesis menunjukkan angka signifikansi sebesar $0.008(<0.05)$, sehingga H1 terdukung secara statistik.

Seperti pendapat yang dikemukakan oleh Heinze (1976) bahwa profitabilitas merupakan faktor yang menjadikan manajemen lebih bebas dan fleksibel dalam mengungkapkan CSR kepada shareholder dan stakeholder.Profitabilitas yang semakin tinggi akan membuat manajemen dapat melakukan dan mengungkapkan aktivitas CSR secara lebih luas. Sehingga dapat disimpulkan bahwa, CSRakan meningkatkan nilai perusahaan pada saat profitabilitas perusahaan meningkat (Hackston dan Milne, 1996). Begitupun dalam penelitian ini pada perusahaan publik sektor pertambangan yang terdaftar di BEI tahun 2012-2016, yaitu dengan adanya profit mampu memperkuat pengaruh CSR terhadap nilai perusahaan.

\section{Uji Hipotesis 6 : Kepemilikan manajemen memperkuat hubungan antara CSR dan nilai perusahaan publik sektor pertambangan.}

Hasil penelitian ini menunjukkan bahwa kepemilikan manajemen perusahaan tidak memperkuat hubungan antara CSR dan nilai perusahaan publik sektor pertambangan yang terdaftar di Bursa Efek Indonesia periode tahun 2012 - 2016.Uji hipotesis menunjukkan angka signifikansi sebesar 0.582 (> 0.05), sehingga H1 tidak terdukung secara statistik.

Kepemilikan manajemen dalam penelitian ini memperlemah hubungan antara CSR dan nilai perusahaan karena disebabkan oleh jumlah saham yang dimiliki oleh dewan direksi dan komisaris pada perusahaan pertambangan yang menjadi sampel penelitian masih terhitung rendah jika dibandingkan dengan jumlah saham perusahaan yang beredar di pasar.Hal ini terlihat dari rata-rata kepemilikan manajemen masih terhitung sedikit yaitu hanya sekitar $8.89 \%$. Bahkan kepemilikan manajemen yang paling rendah dari perusahaan pertambangan yang menjadi sampel penelitian menunjukkan jumlah yang sangat sedikit, yaitu hanya sebesar 0.000001 atau 0,0000085\%. Kepemilikan manjemen terendah ini ada pada perusahaan PT Golden Energy Mines Tbk (GEMS) tahun 2012.

\section{Uji Hipotesis 7 : Ukuran perusahaan memperkuat hubungan antara $C S R$ dan nilai perusahaan publik sektor pertambangan.}

Hasil penelitian ini menunjukkan bahwa ukuran perusahaan perusahaan tidak memperkuat hubungan antara CSR dan nilai perusahaan publik sektor pertambangan yang terdaftar di Bursa Efek Indonesia periode tahun 2012 - 2016.Uji hipotesis menunjukkan angka signifikansi sebesar 0.253 ( $>0.05)$, sehingga secara statistik tidak mendukung H1.

Akan tetapi, hasil penelitian ini menunjukkan bahwa ukuran perusahaan tidak mampu memperkuat pengaruh CSR terhadap nilai perusahaan atau semakin besar suatu perusahaan belum tentu memiliki tanggungjawab untuk mengungkapkan kegiatan CSR semakin luas. Hasil penelitian bisa disebabkan karena adanya UU No. 40 Tahun 2007 yang mewajibkan setiap perusahaan yang memanfaatkan SDA wajib untuk melaksanakan kegiatan Tanggung Jawab Sosial dan Lingkungan, sehingga besar atau kecil ukuran perusahaan tersebut harus tetap mengungkapkan kegiatan CSR yang telah dilakukan dalam annual report perusahaan.

Keadaan ini juga mengindikasikan bahwa untuk mendapatkan legitimasi perusahaan dari para stakeholders, perusahaan tidak akan selalu menerbitkan annual report atau sustainability report untuk menambah kepercayaan terhadap perusahaan baik dari pihak internal maupun eksternal yang mempunyai kepentingan terhadap perusahaan. Hal ini disebabkan karena pengungkapan CSR bukan lagi hanya menjadi sebuah kegiatan sukarela, akan tetapi merupakan sebuah kewajiban untuk menjaga kelangsungan hidup perusahaan, sehingga besar kecilnya suatu perusahaan tidak memengaruhi besarnya tingkat pengungkapan CSR perusahaan.

\section{Kesimpulan Dan Saran}

Berdasarkan hasil penelitian dan pembahasan, maka kesimpulan dalam penelitian ini adalah sebagai berikut.

1) CSR tidak berpengaruh terhadap nilai perusahaan publik sektor pertambangan yang terdaftar di Bursa Efek Indonesia periode tahun 2012 - 2016.

2) Profitabilitas berpengaruh positif terhadap nilai perusahaan publik sektor pertambangan yang terdaftar di Bursa Efek Indonesia periode tahun 2012 - 2016.

3) Kepemilikan manajemen tidak berpengaruh terhadap nilai perusahaan publik sektor pertambangan yang terdaftar di Bursa Efek Indonesia periode tahun 2012 - 2016.

4) Ukuran perusahaan tidak berpengaruh terhadap nilai perusahaan publik sektor pertambangan yang terdaftar di Bursa Efek Indonesia periode tahun 2012 - 2016.

5) Profitabilitas memperkuat hubungan antara CSR dan nilai perusahaan publik sektor pertambangan yang terdaftar di Bursa Efek Indonesia periode tahun 2012 - 2016. 
6) Kepemilikan manajemen tidak memperkuat hubungan antara CSR dan nilai perusahaan publik sektor pertambangan yang terdaftar di Bursa Efek Indonesia periode tahun 2012 - 2016.

7) Ukuran perusahaan perusahaan tidak memperkuat hubungan antara CSR dan nilai perusahaan publik sektor pertambangan yang terdaftar di Bursa Efek Indonesia periode tahun 2012 - 2016.

Berdasarkan hasil penelitian dan pembahasan serta kesimpulan, maka saran yang dapat diberikan adalah sebagai berikut.

1) Bagi pemerintah, disarankan untuk bisa membuat regulasi baru mengenai pengungkapan $C S R$ yaitu memperjelas indikator-indikator $C S R$ yang harus diungkapan oleh perusahaan dalam laporan tahunan perusahaan.

2) Bagi perusahaan, disarankan agar menggunakan suatu pedoman atau standar yang komprehensif dalam pengungkapan kegiatan $C S R$, seperti standar yang umum digunakan dan berlaku secara internasional yaitu pedoman pelaporan keberlanjutan oleh Global Reporting Initiative (GRI). Standar pelaporan GRI yang terbaru adalah standar $G 4$.

3) Bagi investor, disarankan agar tetap mempertimbangkan kegiatan CSR dengan membaca pengungkapan yang dimuat dalam annual report untuk pengambilan keputusan investasi meskipun hal tersebut merupakan mandatori sesuai dengan amanat UU, mengingat belum adanya regulasi yang jelas dari Pemrintah Indonesia tentang indikator pengungkapan CSR. Sehingga bisa diketahui perusahaan yang melaksanakan kegiatan CSR secara komprehensif dan tidak.

4) Bagi peneliti selanjutnya, disarankan untuk memperluas objek penelitian yaitu mencakup sektor lain di Bursa Efek Indonesia atau pun perusahaan yang terdaftar di bursa efek internasional.

5) Bagi peneliti selanjutnya, disarankan untuk menambah tahun pengamatan sehingga hasil analisis bisa lebih jelas dan lengkap.

6) Bagi peneliti selanjutnya, disarankan untuk bisa menambah variabel yang bisa memoderasi hubungan CSR dan nilai perusahaan, seperti variabel leverage.

7) Bagi peneliti selanjutnya, disarankan untuk melibatkan pihak lain dalam menentukan luas pengungkapan sebagai bahan pemeriksaan kembali untuk meminimalisasi subjektifitas.

\section{Daftar Pustaka}

Adam, M and P. Hardwick (1998), “An Analysis of Corporate Donations: United Kingdom Evidence”, Journal of Management Studies 35 (5), 641-654.

Agustine, I (2014), "Pengaruh Corporate Social Responsibilityterhadap Nilai Perusahaan”, FINESTA 2 (1), $42-$ 47.

Anggraini, R.R ( 2006), Pengungkapan Informasi Sosial dan Faktor - Faktor yang Mempengaruhi Pengungkapan Informasi Sosial dalam Laporan Keuangan Tahunan.Simposium Nasional Akuntansi IX.Padang, Agustus, 23-26.

Bowman, E and K. Haire (1988), "The Public Disclosure of Environmental Performance Information: A Dual Test of Media Agenda Setting Theory and Legitimacy Theory", Accounting and Business Research 29 (1), 1-25.

Cowen, S.S., L.B. Ferreri, and L.D. Parker (1987), "The Impact of Corporate Characteristics on Social Responsibility Disclosure: A Typology and Frequency Based Analysis”, Accounting, Organizations and Society, 12(2), 111-122.

Crowther, D and G. Aras (2008), Corporate Social Responsibility.USA: Ventus Publishing ApS

Eklington, J (1997), Cannibals with Forks The Triple Bottom Line of $21^{\text {st }}$ Century Business. Oxford: Capstone Publishing Ltd.

Epstein, M.J and M. Freedman (1994), “Social Disclosure and the Individual Investor”, Accounting, Auditing \& Accountability Journal (7) 4, 94-109.

Fuerst, O and Sok-Hyon Kang (2004), "Corporate Governance, Expected Operating Performance, and Pricing”, Corporate Ownership \& Control 1 (2), Winter, 13-30.

Ghoul, El. Sadok, O. Guedhami, C.Y. Chuck, Kwok, and D.R. Mishara (2011), "Does Corporate Social Responsibility Affcet the Cost of Capital?”, Journal of Banking \& Finance 35 (9), 2388-2406.

Gray, Rob, R. Kouhy, dan S. Lavers (1995), "Corporate Social and Environmental Reporting: A Review of The Literature and A Longitudinal Study of UK Disclosure", Accounting, Auditing, and Accountability Journal 8 (2), 47-77.

Hackstone, D and M.J. Milne (1996), "Some Determinants of Social and Environmental Disclosures in New Zealand Companies", Accounting, Auditing \& Accountability Journal 9 (1), 77-108.

Heinz, D.C (1976), "Financial Correlates of A Social Measure", Akron Business and Economic Review 7 (1), 4851.

Hemastuti, C.P (2014), "Pengaruh Profitabilitas, Kebijakan Dividen, Kebijakan Hutang, Keputusan Investasi dan Kepemilikan Insider terhadap Nilai Perusahaan”, Jurnal Ilmu \& Riset Akuntansi 3 (4), 1-15.

Kamil, A dan A. Herusetya (2012), "Pengaruh Karakteristik Perusahaan Terhadap Luas Pengungkapan Kegiatan Corporate Social Responsibility”, Media Riset Akuntansi2(1), 1-17. 
Lerner, L.D dan G.E. Fryxell (1988), “An Empirical Study of the Predictors of Corporate Social Performance: A Multi-Dimensional Analysis", Journal of Business Ethics 7, 951-959.

Mahatma, D., A. Sri dan A. Wirajaya (2013), "Pengaruh Struktur Modal, Profitabilitas dan Ukuran Perusahaan pada Nilai Perusahaan", E-Jurnal Akuntansi Universitas Udayana 4 (2). 358-372.

Martini, Ni Nyoman G. Putu, Moeljadi dan Djumahir (2014), "Factors Affecting Firms Value of Indonesia Public Manufacturing Firm” International Journal of Business and Management Invention 3 (2), 35-44.

McWilliams, A and D. Siegel (2000), "Corporate Social Responsibility and Financial Performance: Correlation or Misspesification?",Strategic Management Journal 21 (5), 603-609.

O’Donovan, G (2002), “Environmental Disclosures in The Annual Report: Extending The Applicability and Predictive Power of Legitimacy Theory", Accounting, Auditing, and Accountability Journal 15 (3), 344371.

Putri, H.C.M dan S. Raharja(2013),"Pengaruh Corporate Social Responsibility terhadap Nilai Perusahaan dengan Kepemilikan Manajerial sebagai Variabel Moderating”,Diponegoro Journal of Accounting 2 (3), 1-5.

Rosiana, G.A.M.E., Gd. Juliarsa, dan M.M.R. Sari (2013), "Pengaruh Pengungkapan CSR terhadap Nilai Perusahaan dengan Profitabilitas sebagai Variabel Moderasi”, E-Jurnal Akuntansi Universitas Udayana, 5 (3) $723-738$.

Sembiring, E.R (2006), "Karakteristik Perusahaan dan Pengungkapan Tanggung Jawab Sosial: Study Empiris pada Perusahaan yang Tercatat di Bursa Efek Indonesia Jakarta", Jurnal Maksi Universitas Diponegoro Semarang 6 (1), Januari, 69-85.

Siallagan, H dan M. Machfoed (2006), Mekanisme Corporate Governance, Kualitas Laba dan Nilai Perusahaan.Simposium Nasional Akuntansi 9. Padang. 23-26 Agustus.

Soliha, E dan Taswan(2002)“Pengaruh Kebijakan Hutang Terhadap Nilai Perusahaan Serta Beberapa Faktor yang Mempengaruhinya”Jurnal Bisnis dan Ekonomi STIE Stikubank2 (1), 8-12.

Suharli, M (2006), "Studi Empiris pada Faktor-faktor yang Mempengaruhi Nilai Perusahaan pada Perusahaan Go Public di Indonesia",Jurnal Maksi 6 (1), Universitas Indonesia Katholik Atmajaya.

Sujarweni, V.W (2016), Kupas Tuntas Penelitian Akuntansi dengan SPSS.Yogyakarta: Pustaka Baru Press.

Tandelilin, E (2001), Analisis Investasi dan Manajemen Portofolio. Yogyakarta: PT. BPFE.

Undang-undang No. 40 Tahun 2007 Tentang Perseroan Terbatas. 